\title{
Online Access
}

This journal is available online in $\mathbf{2 0 0 0}$

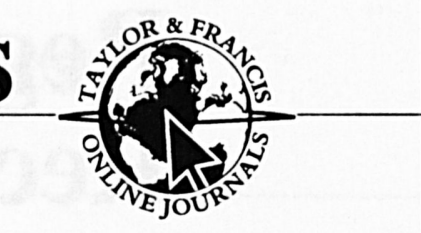

Institutional subscribers to the print version of this volume can enjoy online access to the same volume (and in some cases to the electronic archive) free of charge. Journals are currently available in a choice of PDF or RealPage formats through a simple-to-use web interface provided by CatchWord.

\section{KEY BENEFITS}

- Fully searchable database

- Active reference linking

- Easy access to full text

- Multi-format delivery options

- IP access control

- Cross journal searching

- Contents alerting service

Please connect to http://www.tandf.co.uk/online.html for further information and follow the steps set out on the 'Getting Started' page at the CatchWord web site: http://www.catchword.co.uk to enable access.

\section{SEND AN E-MAIL TO:}

CatchWord Helpdesk - support@ catchword.co.uk Online Customer Services Department - online@tandf.co.uk 


\section{Register to}

Receive Contents

Pages by E-mail

\section{Scholarly Articles Research Alerting}

We will e-mail you the contents pages of any of our journals before we mail out the hard copy. This will give you advance notice of what is being published, enabling you to receive details of contents before the journals arrive in your library. You may subscribe to individual journals as well as to journal subject groups. For those journals which are available online your e-mail will contain links to the online contents.

To register your interest in this complimentary service, please send an e-mail to SARA@ @andf.co.uk with the word 'info' in the body of the message.

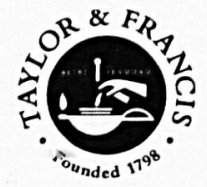

Further details are available on our web site at http://www.tandf.co.uk/journals 


\section{Europe-Asia Studies}

\section{formerly Soviet Studies}

\section{EDITOR}

Roger Clarke, University of Glasgow, UK Supported by a Board of Management, National Advisory Board and International
Editorial Consultants

Following the collapse of the Soviet Union in 1991, the Editors took the decision to change the title of the long-established Soviet Studies (published since 1949) to Europe-Asia Studies.

Europe-Asia Studies has maintained its reputation as the principal academic journal in the world devoted to the political, economic and social affairs of what were once the Soviet bloc countries, including their history during the Soviet period. At the same time the focus of the journal has diversified to reflect the way in which the transformation of the former Soviet countries' political and economic systems is affecting their relationship with the rest of Europe, and the growing links between what was Soviet Central Asia and other countries in both Europe and Asia. The comparison with the similar transformation taking place in China is a further addition to the general broadening of the field once known as Soviet Studies.

This journal is also available online.

Please connect to http://www.tandf.co.uk/online.html for further information.

\section{SUBSCRIPTION RATES}

2000 - Volume 52 (8 issues)

Print ISSN 0966-8136

Online ISSN 1465-3427

Institutional rate: US $\$ 564 ; £ 338$ (includes free online access)

Personal rate: US $\$ 184 ; £ 98$ (print only)

\section{ORDER FORM}

PLEASE COMPLETE IN BLOCK CAPITALS AND RETURN TO THE ADDRESS BELOW

Please invoice me at the $\square$ institutional rate $\square$ personal rate

$\square$ Please send me a sample copy

Name

Address

E-mail 


\section{Journal of Ethnic and Migration Studies}

\section{EDITOR}

Malcolm Cross, Centre for European Migration and Ethnic Studies (CEMES)

\section{ASSOCIATE EDITORS}

Stephen Castles, University of Wollongong, Australia

Roger Waldinger, University of California at Los Angeles, USA

\section{EDITORIAL MANAGER}

\section{Jette Johst}

Supported by an International Editorial Board

The Journal of Ethnic and Migration Studies (JEMS) is the leading journal in its field with an emphasis on advanced industrial societies. Originally published under its old title New Community since 1971, the journal specialises in research-based articles on all forms of migration and its consequences, together with articles on ethnic conflict, discrimination, nationalism, citizenship and policies of integration.

Contributions to the journal, which are fully refereed by independent scientific specialists, are especially welcome when they report on comparative research. Contributions are invited from any branch of the social sciences, and the results of inter-disciplinary research are of particular interest. JEMS publishes special issues on a regular basis and the editor is always pleased to recieve proposals for collections of articles on a relevant theme.

JEMS has a long-standing interest in policy debates and in the evaluation of policy initiatives. Its coverage includes reports on policy initiatives. The book review section aims to cover the most important titles, and sections on 'Research Notes' and 'Debates' are included on a regular basis.

This journal is also available online.

Please connect to http://www.tandf.co.uk/online.html for further information.

\section{SUBSCRIPTION RATES}

\section{0 - Volume 26 (4 issues)}

Print ISSN 1369-183X Online ISSN 1469-9451

Institutional rate: US $\$ 328 ; £ 198$ (includes free online access)

Personal rate: US\$68; $£ 41$ (print only)

\section{ORDER FORM}

PLEASE COMPLETE IN BLOCK CAPITALS AND RETURN TO THE ADDRESS BELOW

Please invoice me at the $\square$ institutional rate $\square$ personal rate

Please send me a sample copy

Name

Address

E-mail 


\title{
Peace Review
}

\author{
EDITOR \\ Robert Elias \\ SENIOR EDITOR \\ Jennifer Turpin \\ both at Peace and Justice Studies, University of San Francisco, USA
}

Supported by Associate Editors and an International Editorial Advisory Board

Peace Review is a quarterly, multidisciplinary, transnational journal of research and analysis, focusing on the current issues and controversies that underlie the promotion of a more peaceful world. Social progress requires, among other things, sustained intellectual work, which should be pragmatic as well as analytical. The results of that work should be ingrained into everyday culture and political discourse. We define peace research very broadly to include peace, human rights, development, ecology, culture and related issues. The task of the journal is to present the results of this research and thinking in short, accessible and substantive essays. Each issue develops a particular theme whilst also including a number of off-theme essays.

This journal is also available online.

Please connect to http://www.tandf.co.uk/online.html for further information.

\section{SUBSCRIPTION RATES}

2000 - Volume 12 (4 issues)

Print ISSN 1040-2659

Online ISSN 1469-9982

Institutional rate: US $\$ 324 ; £ 196$ (includes free online access)

Personal rate: US\$66; $£ 42$ (print only)

\section{ORDER FORM}

PLEASE COMPLETE IN BLOCK CAPITALS AND RETURN TO THE ADDRESS BELOW

Please invoice me at the $\square$ institutional rate $\square$ personal rate

$\square$ Please send me a sample copy

Name

Address

E-mail 


\section{Post-Communist Economies}

\section{Formerly Communist Economies \& Economic Transformation}

\section{EDITORIAL BOARD}

Professor Morris Bornstein, University of Michigan, USA; Roger Clarke (Editor), University of Glasgow, UK; Professor Philip Hanson, CREES, University of Birmingham, UK; Dr Jacek Rostowski, CEU, Budapest, Hungary; Professor Bruno Schönfelder, Bergakademie Freiberg, Germany and Dr Ljubo Sirc, CRCE, London, UK

Supported by an International Advisory Council

Post-Communist Economies is the new title, from Volume II, 1999, of the journal previously known as Communist Economies and Economic Transformation. After ten years of publication, the title has been changed because of a growing feeling that the major processes into which transformation has generally been divided - stabilisation, liberalisation and privatisation - have in substantial measure been completed in most of the former communist countries, even though this is more true of some than others, and all still have some distance to go to match the long-established market economies in these respects.

Yet despite the dramatic changes that have taken place in the past decade, the postcommunist economies nonetheless still form a clearly identifiable group, presenting distinctive problems. The focus may thus have moved on from basic transformation, but the particular problems of the post-communist economies will continue to be an important area of economic and political analysis. Post-Communist Economies will contribute to this analysis by publishing the key research and policy articles in the field.

This journal is also available online.

Please connect to http://www.tandf.co.uk/online.html for further information.

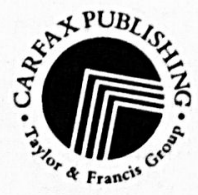

\section{SUBSCRIPTION RATES}

2000 - Volume 12 (4 issues)

Print ISSN 1463-1377 Online ISSN 1465-3958

Institutional rate: US $\$ 542 ; £ 288$ (includes free online access)

Personal rate: US\$152; $£ 84$ (print only)

\section{ORDER FORM}

PLEASE COMPLETE IN BLOCK CAPITALS AND RETURN TO THE ADDRESS BELOW

Please invoice me at the $\square$ institutional rate $\square$ personal rate

$\square$ Please send me a sample copy

Name

Address

E-mail 
NATIONALITIES PAPERS is the only journal in the world which deals exclusively with all nationalities of the former USSR, and also with national minorities in Eastern and Central European countries. The problems and importance of over 140 million people are treated with the disciplinary and methodological contexts of Post-Soviet and Europe-Asia studies. Of central concern is the fate of the Balts, Ukrainians, Jews and the peoples of Central Asia and the Caucasus. Nationalities Papers is an international and multidisciplinary journal with contributors and readers throughout North America, Western and Eastern Europe, the Far East, Japan and the People's Republic of China. Included in each general issue are in-depth analyses from the historical view, updates on latest developments, some original documents, and book reviews; some issues concentrate on a region or nationality as a special topic, which exclusive focus allows for more extensive and detailed information.

Submission of manuscripts. Authors should send the final, revised version of their articles in both hard copy paper and electronic disk forms. It is essential that the hard copy (paper) version exactly matches the material on disk. Please print out the hard copy from the disk you are sending. Submit two printed copies of the final version with the disk to Dr Nancy M. Wingfield, Nationalities Papers, Department of History, Northern Illinois University, DeKalb, IL 60115, USA. Save all files on a standard 3.5 inch highdensity disk. We prefer to receive disks in Microsoft Word for Windows or WordPerfect, but can translate from most other common word-processing programs. Please specify which program you have used. Do not save your files as "text only" or "read only". For further details on Electronic Submission, please visit the Taylor \& Francis Website at: http://www.tandf.co.uk/journals

Business correspondence, including orders and remittances relating to subscriptions, back numbers and offprints, should be addressed to the publisher: Carfax Publishing, Taylor \& Francis Ltd, Customer Services Department, Rankine Road, Basingstoke, Hants RG24 8PR, UK.

Advertising enquiries should be addressed to Philip Law, Carfax Publishing, Taylor \& Francis Ltd, PO Box 25, Abingdon, Oxfordshire OX14 3UE, UK.

Copyright. It is a condition of publication that authors vest copyright in their articles, including abstracts, in The Association for the Study of Nationalities. This enables us to ensure full copyright protection and to disseminate the article, and the journal, to the widest possible readership in print and electronic formats as appropriate. Authors may, of course, use the article elsewhere after publication provided that prior permission is obtained from Taylor \& Francis Ltd. Authors are themselves responsible for obtaining permission to reproduce copyright material from other sources.

THE ASSOCIATION FOR THE STUIYY OF NATIONALITIES

New York

Phone: +12128546239

President David Crowe, Elon College, USA

Vice-Presidents Dominique Arel, Brown University, USA

Lowell Barrington, Marquette University, USA

Sue Davis, Grand Valley State University, USA

André Liebich, Graduate Institute of International Studies, Switzerland

Treasurer Steven Sabol, University of North Carolina, USA

Secretary Bhavna Dave, University of London, UK 


\section{Nationalities Papers}

\section{VOLUME 28 NUMBER 3 SEPTEMBER 2000}

\section{ARTICLES}

Folk, Faith and Fatherland: Defining the Polish Nation in 1883

Patrice M. Dabrowski

Entre Invention et Construction des Traditions: L'héritage Historique et Culturel des Albanais

Albert Doja

The Formation of Azerbaijani Collective Identity in Iran

Brenda Shaffer

Conflict and Catharsis: A Report on Developments in Dagestan Following the Incursions of August and September 1999

Enver Kisriev and Robert Bruce Ware

\section{FORUM: GENDER, NATION, AND MEMORY}

Rotating Spheres: Gendered Commemorative Practice at the 1903 Jan Hus Memorial Festival in Prague

Cynthia Paces

The "Revolutionary Girl with the Titus-Head": Women's Participation in the 1919 Revolutions in Budapest and Munich in the Eyes of their Contemporaries Eliza Johnson

Gender, Memory, and National Myths: Ol'ga Berggol'ts and the Siege of Leningrad

Lisa Kirschenbaum

REVIEW ARTICLE 565

BOOK REVIEWS 587

Scholarly Articles Research Alerting

To receive contents pages by

e-mail visit our Website at:

http://www.tandf.co.uk/journals

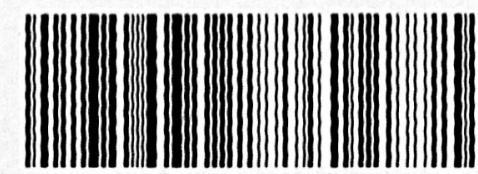

ดロ9ด-5992(200009)28:3:1-G 